\title{
Amending wrongs: notes on the politics of reparation in Brazil: an attempt to come to terms with its past human rights abuses*
}

\section{Sobre as políticas públicas de reparação no Brasil: acertando as contas com as violações dos direitos humanos}

\begin{abstract}
Concentrating on different levels of acknowledgment of past wrongdoings being adopted by Brazilian politics through the transition to democracy, it is aimed to ponder the discussions regarding how Brazilian strategies have confronted the inheritance of its past human rights abuses. For that goal, it will be considered as a theoretical background the sense of reparation on the processes of coming to terms with past injustices. Through the projects developed by the Special Commission on Political Deaths and Disappearances and by the Amnesty Commission, it is proposed to consider how the Brazilian State acknowledges the injustices perpetrated during its military dictatorship, focusing on what role can reparations play on the possibility of building positive approaches, constructing a theory of reparation relationships and attitudes which, without historical understanding informed by consistency and sensitivity, there is no past to come to terms with.
\end{abstract}

Keywords: Special Commission on Political Deaths and Disappearances. Brazilian Amnesty Commission. Politics of reparation.

\section{Resumo}

O reconhecimento oficial das vítimas e das injustiças cometidas pela ditadura militar, oriundo de projetos de reparação agenciados pelo Estado brasileiro, tem possibilitado iniciativas, conquanto escassas e insuficientes, que procuram dar legitimidade à atuação da sociedade civil em busca da superação das violações dos direitos humanos. Tal reconhecimento tem contribuído para a construção de estratégias de implementação de medidas transicionais essenciais à reparação simbólica de injustiças históricas, rumo ao estabelecimento de novas compreensões valorativas sobre a violência do Estado. Por conseguinte, almeja-se atentar à dinâmica deste reconhecimento por meio das estratégias de acerto de contas com o passado desenvolvidas pelas políticas públicas de reparação agenciadas pela Comissão Especial sobre os Mortos e Desaparecidos Políticos e pela Comissão de Anistia do Ministério da Justiça do Brasil à confrontação da herança das graves violações dos direitos humanos perpetradas pelos agentes da repressão.

Palavras-chave: Políticas públicas de reparação. Comissão Especial sobre os Mortos e Desaparecidos Políticos. Comissão de Anistia. 


\section{Introduction}

The heart cannot forget unless it contemplates what it declines. Emily Dickinson

Over the last decades, many countries have gone through the process of transition from authoritarian regimes to democratic ones, which have brought about various ways of dealing with past injustices. Hence, concentrating on the acknowledgment of past wrongdoings adopted by Brazilian politics through the transition to democracy, it is aimed to ponder the discussions regarding how Brazilian strategies have confronted the inheritance of its past policies, considering as theoretical background the sense of reparation on the processes of coming to terms with a past that haunts the present and does not wish to pass. The term "reparation" - understood as a general expression provided to persons damaged by criminal acts as a fundamental moral intuition that those harmed by wrongdoings, or their descendants, should receive some form of redress - has been an indispensable complement to a broader extent of human rights ideas by strengthening the notion of human rights, suggesting activities that are oriented to repair disrupted relations from the past, honoring and restoring the dignity of history's victims and discouraging new occurrences of injustices.

Although the term "reparation" comprehends a variety of types of redress - including restitution, compensation, rehabilitation, satisfaction, and guarantees of non repetition - it has arisen as the most broadly used term to denote a process of coming to grips with past injustices. Employed in the design of programs with massive coverage or serious violations of international humanitarian law, the term, loosely defined, refers to the attempts to provide benefits to the victims, contemplating a crucial element of politics of accountability in a context that the injustices in question were violent and traumatic. In this sense, the considerations addressed here aim to contemplate the claims for reparations that have recently emerged in Brazil, whereas they confront the processes of settling accounts with a past injustice emphasizing the harm and the need to restore relationships, and reestablish a sense of stability and consistency that is a necessary societal response to the conditions of an experience that has never been fully integrated into understanding. Considering that existential, psychological, and socio-political notion, this essay refers to the efforts of public programs of reparation conducted by the Special Commission on Political Deaths and Disappearances (Comissão Especial sobre Mortos e Desaparecidos Políticos - CEMDP) and by the Amnesty Commission from the Brazilian Ministry of Justice (Comissão de Anistia do Ministério da Justiça do Brasil).

Having in mind that in Brazil the public memory has been branded by silence, omission, and denial, depicted by the notion of an "unmastered past" (SCHNEIDER, 2011, p. 206), it is essential to understand in which extent these commissions could constitute a way of showing respect and esteem for the victims, acknowledging the harms committed - promoting the development of social solidarity, of collective memory and of a critical posture towards state institutions -, developing and performing the foundation for a reflectively empathic, acceptable, and critical version for the difficult truth of an arduous period in a State's history. This is crucial to determine to what extent should we establish a victim's version about past traumatic injustices - a past experience which is not absent and has the difficulty, sometimes the impossibility, of been remembered due to its horror, unexpectedness, numbness, and that is not yet fully assimilated, absorbed or appropriated by the traumatized itself - or what in the individual and collective traumatic historical experience should not be denied and deserves to be mediated, confronted, and preserved in living traditions.

To begin with, it is important to highlight what Marcelo Torelly (2012, p. 261) notices to be a spectrum that has left traces of a mentality characterized by the maintenance of a set of values attached to the public machinery by the Armed Forces, which remained a powerful institution in the post military dictatorship in Brazil. It is a characteristic of such mentality defending the importance of the so celebrated 1964 "revolution" employed in the urban infrastructure, exhibiting the names of public agents that committed human rights violations, or even in school books, which treat dictators as "presidents" and the political repression as a "necessary evil" to safeguard Brazil from the terrorist, subversive and communist threat.

Despite this stigma, in the last decades, the mechanisms for overcoming the legacy from the past crimes of serious human rights violations implemented by the National State Forces, the civil society and international organizations that aim to ensure the democratic institutional prosperity have created a new normative field 
regarding the State legal obligations. While in Brazil the Armed Forces still detained substantial control over the government, the employment of such standardization, as a way of coming to terms with the past and edifying a desired future, has aimed to overcome some grievance and contribute to the peacebuilding, longing to rebuild trust relationships between the State and its citizens, transforming the crimes into learning how not to repeat and how to disseminate values that comply with the respect towards axiological elaboration built from a symbolic plan of resistance and social action through the protection of dignity and suffering prevention.

\section{Reparation commissions: in the search for amending past wrongdoings}

Over the 1970s - even though restricted to left groups linked to the resistance against the regime, especially by the initiative taken by the next of kin of those who suffered political deaths and disappearances (DIMOULIS, 2010, p. 95) -, the Brazilian transitional process was characterized by the accumulation of forces against the military regime, going through fight for and organization of amnesty committees, which gained impulse from 1975 onwards, culminating with the hunger strike for amnesty from political prisoners and with the promulgation of the Amnesty Law (n. 6683) in 1979. Even if it granted impunity to military officials involved in the repressive organs, consolidating an official speech of oblivion, the Amnesty Law ended up conjecturing measures that restore political rights and work reintegration, translating itself into an act of acknowledging the right to resist oppression (TORELLY, 2012, p. 182-183).

If, on the one hand, the Amnesty Law was applied as a legal basis for the agents of State criminality to be granted amnesty, on the other hand, even though consented in impunity circumstances - as it should be sanctioned with a democratic approval (MALLINDER, 2007, p. 226) -, the coexistence of social forces shows to be altered. Therefore, in this circumstance, the regime promulgated an amnesty law that, even being biased, was socially efficient because it allowed the political rights of many citizens to be restored, a great deal of political prisoners to be released, the ones in exile to return to their homeland, and public servants laid off due to political persecution to be readmitted (ABRÃO; TORELLY, 2012, p. 179). Such outcomes have been strengthened by adopting restorative measures to political rights of Brazilian prisoners or in exile, political fugitives to recover their freedom of identity, and human rights defense, the demand of state violence, and claims for the return of democracy to be taken into consideration (ABRÃO; TORELLY, 2012).

Therefore, in the context of impasse manifested by the contradiction of a supposed reciprocity in the Amnesty Law, amnesty represented an attempt to reconcile the country, to pragmatically reestablish the relationship between militaries and opponents who were outlawed, revoked, arrested or exiled: an uncomfortable and painful price paid for the guarantee of an indispensable step toward the establishment of the rule of law and the constitutional democratic order. With the 1988 Constitution, it was recomposed formally and effectively the separation between the Forces that the military regime had buried, ensuring the Public Ministry the defense of the democratic regime, the social and individual interests and the legal order.

The first landmark in the process of redemocratization in Brazil, it is in the Amnesty Law, approved by the Brazilian National Congress in August 1979 - when the State had already carried the burden of economic decline, the inconsistency of maintenance of political authoritarianism, added to internal divergences and misunderstandings, to intensified social mobilization that led to the decision of expanding to a political openness of the regime, at a tortoise's pace, "slowly, gradually and safely" -, that the origins of the current reparation program to the Brazilian politicians who were granted amnesty are found.

It is important to note that the first improvements in the process of amending past injustices in Brazil only actually came out as the military lost authority and, simultaneously, as democracy has matured and human rights were integrated into the national agenda. Even though it is important to emphasize that the Brazilian transition experience has been enabled through the repression inherited from the military regime and through the lack of implementation of legal obligations assumed by the Brazilian State in the field of human rights regarding investigation, punishment, and judgment of serious human rights violations, threatening the assessments of social reality.

Overall, in the context of transitional justice, the projects incorporated to the domain of restaurative justice in Brazil, even though taking too long to be imple- 
mented $^{2}$, conjectured the creation of two reparation commissions: the Special Commission on Political Deaths and Disappearances (1995) and the Amnesty Commission (2002), promoting measures of pecuniary and symbolic reparation to the opponents and dissidents harmed by military repression, and fostering the public debate over the perpetrators accountability. Such measures allowed certain initiatives for overcoming impunity related to crimes against human rights to be taken into action, developing the basis of democratic legitimation and consolidating mechanisms of resistance towards authoritarianism, allowing that the validity of amnesty granted to the agents of the penal subsystem responsible for the torture, deaths and forced disappearances from members of the resistance to be questioned, and that measures of effectiveness to the right to justice, memory and the truth to be improved. Such "politics of memory" would bring about the current debate on the recently established National Truth Commission (CNV), which already represents a milestone in the struggle for a public memory culture, being still able to produce even more advances into accountability mechanisms, rebuilding or transforming relationships and restoring community, consolidating and protecting human rights. ${ }^{3}$

2 After the elapsed time that would keep society identifying with the victims of persecution and repression, the projects incorporated to the domain of transitional justice in Brazil ended up being substituted due to the lack of clamor from the population in order for the agents of repression and the ones who gave orders to be punished. Moreover, from the conciliator character between the new and the former political authorities in the negotiated transition on Brazil, the possibility of punishment of State crimes ended up being dependent on the remaining power or political strength from leaders who couldn't see reasons to punish the crimes perpetrated by themselves. (SWENSSON JUNIOR, 2007, p. 121124)

3 In this context, according to the document "Technical opinion on the nature of crimes against humanity, the imprescriptibility of certain crimes and amnesty prohibition" (Parecer técnico sobre a natureza dos crimes de lesa-humanidade, a imprescritibilidade de alguns delitos e a proibição de anistias) the following treaties for the protection of human rights were ratified by the Brazilian State: International Covenant on Civil and Political Rights (ratified in 1992); Convention against Torture and Other Cruel, Inhuman or Degrading Treatment or Punishment (ratified in 1989); and Convention on the Prevention and Punishment of the Crime of Genocide (ratified in 1952). The International Convention for the Protection of All Persons from Enforced Disappearance was signed by the Brazilian State in 2007, and it has not been ratified yet. In the Inter-American system, the following treaties were ratified by the Brazilian State: American
With the Brazilian transitional process gradual autonomy, despite the irresolution when facing injustices perpetrated by military dictatorship, the solutions offered by the Brazilian State were carefully processed with the edition of the Law of Recognition of Political Deaths and Disappearances (9140/1995) (Law of the Disappeared). This law - from which the first reparation commission was created: Special Commission on Political Deaths and Disappearances (CEMDP) -, sanctioned by the President Fernando Henrique Cardoso 16 years after amnesty, conjectures, in general, the duty of localizing and identifying the remains of those who were political disappeared during the military dictatorship. The law, which determined the formal acknowledgment of responsibility by the Brazilian State for the death of 136 political disappeared persons, was limited to attending the families of the deceased victims, to searching and localizing their remains, to the confirmation of kinship between the relatives and the deceased/missing ones, and to pecuniary compensation.

Due to 11 years of activity from the CEMDP, the book entitled "Right to Memory and to the Truth" (Direito à Memória e à Verdade) was published in August 2007, during Luiz Inácio Lula da Silva's second presidential term, under the coordination of Paulo Vannuchi, Minister of State, and Chief of the Secretariat for Human Rights. This book reports the conclusion of the first phase of analysis and judgment of the processes of 339 cases of deaths and disappearances presented to the Commission to decide, in addition to the 136 cases already recognized by the Law of the Disappeared. Despite the recovery of the remains of many victims from the military dictatorship has not been contemplated, that most of the perpetrators of human rights violations have not been dismissed of authority positions and of offices related to legal practice (substantial absence of depuration), and that the files of

Convention on Human Rights (ratified in 1992); Protocol to the American Convention on Human Rights to Abolish the Death Penalty (ratified in 1994); The Inter-American Convention to Prevent and Punish Torture (ratified in 1986); The Inter-American Convention on The Forced Disappearance of Persons (signed in 1994 - not ratified); Protocol of San Salvador (ratified in 1996); The Inter-American Convention on the Elimination of All Forms of Discrimination Against Persons with Disabilities (ratified in 2001); The Inter-American Convention on the Prevention, Punishment, and Eradication of Violence against Women, "Convention of Belém do Pará" (ratified in 1995). (MÉNDEZ; COVELLI, 2009, p. 370) 
repression have not been unrestrictedly open, it was the first time that the Brazilian State officially revealed the arbitrariness of dictatorship and publicly stated that it was responsible for gross human rights violations.

To the criticism based on the fact that the instituted restorative system was reduced to economical matters - what motivates contempt towards the transitional achievements gained so far, and disrespect to the politically persecuted that, in general, are considered to be "treasure hunters" to the expenses of public funds ${ }^{4}$ -, the works developed by the CEMDP is comprised in its ability to encompass a victim's right to a remedy and some form of acknowledgment of the victim's harm: the death or disappearance of the politically persecuted from September 2, 1961 to August 15, 1979. Despite the adequacy of the compensations offered, the work of the team to be limited by resistance, and the lack of collaboration from the authorities and governmental organs, this commission has created a process of reparation that interacts with the collective plan, allowing a new generation to be integrated to the Brazilian process of transitional consolidation and to be inserted in the construction of a process of reparation. The moral dimension of such initiative is effective in the acknowledgment of victims and human rights violations, contributing to the implementation of transitional measures towards the consolidation of new valuational attributions to faults from the past.

With the Law of the Disappeared - even though the burden of proof has remained under the responsibility of the relatives themselves, many times unable to examine the circumstances of the deaths, disengaging the State to identify and make accountable the ones who committed the crimes -, the victims relatives started to have the right to demand death certificates from the disappeared and to receive the proper economical compensation. From the establishment of the CEMDP, the Brazilian mechanism "to signal a new sort of human rights activity and a response to concrete political dilemmas human rights activists faced in what they understood to be 'transitional' contexts" (ARTHUR, 2009, p. 326) started to take into account different measures that have turned efficient some

4 The derogatory construction of compensatory reparation received by the politically persecuted is also seen in the frequent use of the expression "bolsa-ditadura" ("dictatorship allowance"), argument supported by its own idea of "political agreement" and by the analysis that the redress system in Brazil is limited to pecuniary compensations. resources that allow the right to memory and to the truth to be elaborated through mechanisms that encompass the clarification and acknowledgment of violent situations from the dictatorial State, refuting versions officialized by the offices of repression. To the effective extension of its responsibilities, the Brazilian State lacks the establishment of an apparatus that allows accountability of agents perpetrators of human rights violations, through actions that promote effectiveness and stability to public politics of reparation, reconstituting a contested reality and authorizing a more prolific action of elaboration of the past and working through the memory that fulfill some obligations that, in general, concern the refinement, incentive and defense of human rights.

The reparation politics in Brazil also encompassed the acknowledgment of victims and injustices through the institution of public acts for the official apologizing to the victims of violence from the authoritarian State, featuring effective transitional measures for moral redress that take into account educational actions, politics of memory and truth that aim to restore the dignity of the victims. The integration of such plural symbolic mechanisms of reparation that take into account the acknowledgment of victims and injustices, performing interconnected projects focused on the accomplishment of the right to economic and symbolic reparation, was materialized into three main projects from the Amnesty Commission from the Brazilian Ministry of Justice: the Amnesty Caravans (Caravanas da Anistia), the Political Amnesty Memorial in Brazil (O Memorial da Anistia Política do Brasil), and the Marks of Memory (Marcas da Memória).

Broadly speaking, the Amnesty Caravans, initiated in 2007, are initiatives that are implemented by the itinerant execution of in loco public sessions/hearings of trials for the requests of reparation from politically persecuted. Complemented by cultural and educational activities, the caravans begin their public sessions by paying tribute to the ones who will have their amnesty request at the Ministry of Justice analyzed. Focusing on recovering political memory, made public through the actions promoted by the Amnesty Commission, the Political Amnesty Memorial in Brazil - which shall be inaugurated by the end of 2015 -, will have the overall goal of materializing this collection of dossiers, as well as audio and video documents that recover not only the injustices committed to the persecuted ones, but also Brazil's history from the perspective of the victims of human rights vi- 
olations perpetrated by the Brazilian State between 1946 and 1988. The Amnesty Memorial will congregate the function of museum, research and documentation center, administrated by the Ministry of Justice through the Amnesty Commission Council. Enabling the emergence of the narrative plurality in the social context, the project Marks of Memory, created in 2008, aims transferring resources to actions organized and implemented by groups from the civil society, gathering testimonies, systematizing information and fostering cultural initiatives that, put into action by the Amnesty Commission, stimulate practices that visualize the Brazilian process of transition and the fight for amnesty with memorialistic focus on the perspective of the politically persecuted, conjecturing the experience of reparation as recognition.

The official acknowledgment of the victims of injustices from the Brazilian authoritarian State produced by the projects developed by the reparation commissions - despite the violence originated from the Brazilian dictatorial context is evident "in the ignoble acts of torture still applied in police stations" (TELES, E., 2010, p. 316), and manifested through the use of a vocabulary that considers the daily violence and political repression a mere inanity, or occupational accident in the fight against "terrorists" (TELES, J., 2010, p. 297) -, has enabled initiatives, while insufficient, that try to legitimate the action of civil society in the search of acknowledgment of human rights violations, significantly contributing to the construction of strategies that implement transitional measures towards the establishment of new valuational understanding about the committed injustices. It is about a will to remember towards a progress sustained by politics of reparations, elaboration and formation of a historical memory; a labor of mourning to overcome repetitions through comprehension and clarification promoted by the State, rethinking the relationship between memory, politics and justice, a pedagogical will "to surmount silences and political abuses, to simultaneously be able to distance from and promote an active debate and reflexivity about the past and its meaning for the present/future" (JELIN, 2003, p. 07).

It is difficult to accept that, in a democratic country, the Amnesty Commission programs from the Ministry of Justice have been designated by an Amnesty Commission, and not by a "Reparation Commission for the Victims of the Military Regime", as Glenda Mezarobba (2010b, p. 117) wisely suggests, and also that the victims still need to appeal to an amnesty request at the Ministry of Justice in order to have the injustices committed by the Brazilian government acknowledged. However, it must be considered that the semantic resignification defended by the Amnesty Commission - which proposes that the exercise of forgetting, tied to the meanings of the word "amnesty" itself, promotes politics of memory toward the accomplishment of the right to memory and to the truth, assuming that there is no amnesty from the effects of unsolved traumas - allows non criminal reparation measures to be implemented through the acknowledgment of acts of violence committed by the authoritarian regimes.

The frustrating character of our unfinished transition concerns a process of transitional justice whose available options are characterized by the public politics of reparation and by amnesty. Such alternatives emphasize the search for a reflexive reconstruction of memory and truth; through acknowledging the victims and the violence experienced under political repression; through social accountability, not being the lack of penal legal punishment a synonym for impunity (DIMOULIS, 2010, p. 111); and through a process of historical review, of a "symbolic victory of the defeated ones", of the obligation of the military to embitter a "moral defeat", suffering a "social sanction" (SWENNSSON JUNIOR, 2010, p. 30), of overcoming the Brazilian authoritarian legacy, and of consolidation of democracy.

\section{Some thoughts on the acknowledgment of past wrongdoings in Brazil}

Some criticisms indicate that the Brazilian democracy is somehow silent due to a discourse that disregards Brazilian State accountability for the crimes perpetrated in the past. This silence would be a result of the lack of a public dimension to express what has been lived, of the absence of a public sphere for what Theodor Adorno (1998, p. 102) calls "the reinforcement of a person's self-consciousness", a privation of a social desirable processes and/or essential rites of working through the traumatized memory caused by the atrocities perpetrated by Brazilian authoritarian regimes through collective mourning. This reticence which indicate the indifferences of Brazilian State would deprive a public dimension where society could take into consideration the legitimacy of a shared collectively feelings of distress, melancholy, and revenge intensified by the act of forgetting arranged 
by the censorship, which disrupts any attempt to communicate or overcome the atrocious past (TELES, E., 2007, p. 70). ${ }^{5}$

However the laws and decrees that impede full access to public information - what makes the need to listen to testimonies from those who survived (and their relatives) the violence practiced by the Brazilian authoritarian State even more urgent - and the lack of a public

5 Although no one has been condemned for the crimes perpetrated by the regime, the Brazilian State has been held legally responsible for the torture, imprisonment, death and/ or disappearance of certain victims of political harassment. The first time Brazil was held responsible for it was in 1978, in a case involving the illegal imprisonment of the journalist Vladimir Herzog. The federal government had to pay compensation for material and moral damages to his widow and children. Despite the legal and political barriers that postpone legal decisions and its prosecution, in June 2008, as Glenda Mezarobba observed (2010a, p. 16-17), a struggle to punish dictatorship crimes began to be developed by the Public Prosecutor's Office, after a federal prosecutor from Uruguaiana requested the Federal Police to investigate the involvement of civilians and military agents of the dictatorship in the kidnapping and disappearance of a left wing Italian-Argentine militant (Lorenzo Ismael Viñas) and an Argentine priest (Jorge Oscar Adur) in the border of Brazil and Argentina in 1980. Afterwards, in the same year, the retired Colonel Carlos Alberto Brilhante Ustra was accountable by the Brazilian State for kidnapping and torture during the military regime (MEZAROBBA, 2010a). This was the first official recognition of involvement in acts of torture against civilians. In a case against Brazil in March 2009, the Inter-American Commission on Human Rights (IACHR) inquired the Inter-American Court of Human Rights to determine the international responsibility of the Brazilian State for its failure to accomplish a number of Human Rights obligations, such as the right to personal integrity and the right to life in a case known as Gomes Lund (Guerrilha do Araguaia) vs. Brazil. The IACHR approved the Case Final Report, determining the international responsibility of the Brazilian State for the arbitrary detention, torture and forced disappearance of the victims, considering that the interpretation of the Brazilian Amnesty Law violates the American Convention on Human Rights. After analyzing the information presented to the IACHR by the Brazilian State - who for many years omitted performing military operations against peasants, Indians, and political militants in Pará state -, and due to the lack of adequate implementation of recommendations, the case was then delegated to be judged in Inter-American Court of Human Rights. Brazil was held accountable for the forced disappearance of 62 people between 1972 and 1974 in December 2010 - the year in which Brazil ratified the International Convention for the Protection of All Persons from Enforced Disappearance. The Court decided that the provisions of the Amnesty Law are incompatible with the American Convention and have no legal consequences, determining the State to reveal the truth about the crimes and to criminally investigate the evidences of the case (MEZAROBBA, 2010a, p.17-18). sphere that allows listening to those testimonies, of reflecting over the memories from the authoritarian period, would be partially superseded by public ceremonies of redress whose projects look for clarification and acknowledgment of injustices through apologies and repentance, together with commemorations and tributes associated to the possibility of public testimonial declaration. Such political actions that allow histories and impressions to be revealed, although it cannot be said it has been crowned with unflawed success, have collaborated in building a collective consciousness, dealing with what Jörn Rüsen (2003, p. 29) defines "the loss of a value community [...] as the consequence of historical experience", offering access and meaning to a variety of human experiences, actions, suffering, conservation, and transformation of social and political life through creating an institutional sphere for testimony.

Even though this sphere for testimony "runs the risk of being turned into a banal and overexposed spectacle of horror" (JELIN, 2003, p. 75), since those memories permanently kept in silence within the society have the chance of being critically recalled in memory, pronounced, and articulated, distinguishing between past and present, overcoming the legacy of a certain culture of impunity, it would be possible to deal with national identity "in a way that conforms to historical experiences" (RUSEN, 2003, p. 30). It would be likely to work through its traumatic inheritances while recognizing one is living the present with openings to the future. Even though it must be attempted to the fact that the reenactment of a memory that is problematic to be told seems to evoke what Cathy Caruth (1995, p. 153) names:

The difficult truth of a history that is constituted by the very incomprehensibility of its occurrence", through this process of verbalizing a memory, of integrating it into one's one, and others', exorcising the haunting past that disturbs chronology, of response to the uncomfortable presence of one's own Lebenswelt that refuses to go away due to its traumatic impact, of making sense of it and working it through, one also "acquires the possibility of being an ethical and political agent (LACAPRA, 2001, p. 144).

Although various types of violence have, actually, as Tzvetan Todorov observed (2010, p. 6-7), "survived intact from all the efforts to fight them with memory, and they continue today probably with even greater force" and admitting that this testimonial trend should not, as Elizabeth Jelin (2003) asserts "replace the urgent need 
for political, institutional, and juridical responses to past conflicts, nor [...] overshadow symbolic, oral, or ethical ones" -, it is agreed that a structure of reparation of moral damage can be formulated by policies that aim to make sense of the past, recognizing a special status to the offended. It would liberate the dominion of a past image that needs to be worked through, a memory work embodied on the perceiving and accepting the loss as part of the subject, in mourning toward the future - a process of elaboration and integration of the reality of a traumatic experience, a reenactment of memory that has become what Charles S. Maier (1993, p. 139) terms a "strategy for survival" that needs to be confronted, a fundamental way of overcoming the traumatic past that allows the acknowledgment of harms as such.

Such structure of reparation of moral damage is a condition to give the traumatic experience a historical meaning, to restore the dignity aggrieved by the offense - a form of reassurance and a basis for the establishment of some disposition that mediates social interaction: a mode of attention which encompasses an expectation of a shared normative commitment, a degree of civic trust, as notices Trudy Guvier (2006, p. 59), "to uphold fundamental values, providing a basis for reconstructing state and society".

The levels of acknowledgment of past wrongdoings still being adopted through the projects worked out by public politics of reparations conducted by Brazilian policies - processes that imply interactions through meeting and missing remembrances, lapses and voids, silences and signals, plurals and singulars, objectives and subjectives, in a context of critical discussion among history, psychoanalysis, ethics and politics - has enabled the explicit rescue of a denied past, constructing a theory of reparation and empathic attitudes and unsettlement which, without historical understanding informed by consistency and sensitivity, without attaining to its traumatic elements and its uses of memory for the present and future, there is no wrong to be amended. ${ }^{6}$ Such

6 Since it is a political strategy that turns to history in order to make sense of the past, it must be told that the historians have also to fulfill the duty to speak out about that traumatic past if they do not want to cease to perform their profession. As advertises Jörn Rüsen, consigned to its logic of sense generation, history writing follows the logic of a working through that is embodied in mourning and that would then also achieve a distinct "function of detraumatization" by re- projects - regardless of the fact that the limits and extents of contemporary political action encounter silent paradigms of politics and memory, impunity created by the Amnesty Law, and the lack of access to military files seem to corroborate that traumatic memory (often suppressed "to avoid the suffering of the person who bears them" (JELIN, 2003, p. 74)) can be critically informative, not as an empirical exact representation of its object, as LaCapra observes (1998, p. 41), but as an assimilation frequently followed by the feeling of anguish from all who took part in an event and from their descendants.

This perspective reinforces the argument of humanity and enables the exercise of the right to remember, essential to the symbolic reparation of historical injustices, to the recovery of dignity, and to dealing appropriately with traumatic memories from a past that, even after several years, remains painful or disturbing in our everyday experience. Hence, the rescue of the aggrieved dignity takes place through guidance committed to the acknowledgment of the painful past and through a critical history that may redeem humanity from its indifference, a history that produces anxiety in tolerable and not paranoid doses in order to avoid or contest the propagation of atrocious events (SELIGMANN-SILVA, 2000, p. 41). This homeopathic procedure that does not oppose affective and intellectual or cognitive dimensions of representation corroborates the LaCapra (2001, p. X-xi) statement that as traumatic, then, history is seen "as a response to a felt implication in excess and disorientation which may have to be undergone or even acted out if one is to have an experiential or empathic basis for working it through".

\section{Closing remarks}

Objections emanate in discussing the politics of reparations. It is crucial to take into account the statements that reparations are not sufficiently punitive, that without prosecutions and punishment any reparation is

alizing the loss of meaning, by detaching oneself from this loss with the purpose of assuming it as something that is lost face to face with what actually has happened (RÜSEN, 2003, p. 17-18). Regarding Rüsen, this loss that needs mourning is the one that requires the definition of the individuals own historical identity in an intergenerational context: "only through mourning can the loss be understood as such and at the same time the lost elements of one's historical identity be regained" (RÜSEN, 2003, p. 26). 
misleading, inadequate, and cannot offer a convincing deterrent to future violations. Furthermore, the objections claim that reparations are controversial and exacerbate social conflict, being a threat to social harmony, and regardless of what measures are taken, reparations will always be inadequate to address the serious harms and the undeserved suffering that has been caused. Moreover, as Regula Ludi (2006, p. 450) accurately elucidates, victims, or their descendants, turn out to be dependent of a bureaucracy that regulates their past according to distortions of memory constructions, which leads to an unoptimistic evaluation of the victims' reparation and to the competence to redress the damages and acknowledge the extent caused by human rights violations.

In the context of the Brazilian military dictatorship, the public agents who perpetrated crimes against humanity not only regretted publicly their acts, but also obstructed the access to public documents that registered ambiguous and unclear episodes, insisting in denial and projecting it to groups of the Brazilian society. In spite of this unenfranchisement upon collective political memory and historical consciousness, to the loss of a growing equality - and before critics to the reparation model that shows contempt for transitional progress and the lack of respect for narratives that deny their trauma, and regarding the politically persecuted who were stigmatized by the media as "treasure hunters" or the use of the term "occupational accident" for the violent exercise of repression when combating "terrorists", and even before all imperfection of the transitional process in Brazil - the hermeneutic fight for the significance and elaboration of traumatic episodes experienced during the authoritarian regime is clearly visible.

In Brazil, even if the Judiciary has not been a place where the citizens rights are fulfilled and the Armed Forces insist in performing a disservice by not revealing the totality of the occurred facts, the reparation commissions actions have endorsed initiatives defending a certain kind of memory, justice and truth. Those commissions have allowed such initiatives to be contemplated through the construction of a theory of reparation that seems to attempt to make coming to terms with losses of the past injustices conceivable. From this point of view, aside from those that simply insist on "letting bygones be bygones", suggesting that "past injustices are 'old history' for which the perpetrators should be absolved of responsibility", as John Torpey (2001, p. 357) notices, the conduct of Brazil- ian politics of reparations is a phenomenon that considers the behavior of our predecessors in terms of its effects on the contemporary generations, also supporting, as Lawrie Balfour (2005, p. 790) argued, an array of public history efforts meant to educate the population about acquaintances between past human rights violations and inequalities today, besides making substantial changes in the material and political conditions of some victims.

From this perspective, the management of Brazilian politics of reparations can be seen as a more passive and alternative way of pursuing justice. The creation of reparation measures in cases where trials and punishment have not been the case can display the Brazilian acceptance of moral responsibility as a necessary step shifting the relationships between individuals and constituent groups away from wrath, grievance, and hatred within the acknowledgment and the confidence to build a sense of cooperation and maintainable peace. This reflective attitude supports that amending past injustices would allow a less self-misleading encounter with a structural distress, as well as encourage a further social, historical, and political specificity which includes the elaboration of more appropriate social and political practices and institutions - a compromise that enable the rewriting of history as an approach of mourning, defining individuals historical identity in an "intergenerational context" (RÜSEN, 2003, p. 26) within the construction and transmission of a "shared past" (BARKAN, 2006, p. 25), and of a "certain minimum continuity of civility" (DIMITRIJEVIC, 2011, p. 05).

Despite Tzvetan Todorov's restrictions to the fact that commemorations, such as the ones aiming the acknowledgment of injustices, are sacralizing - simplifying the historical knowledge by aiming the supply of "idols to worship and enemies to hate" (TODOROV, 2002, p. 155) -, or from the point of view that the imprescriptible would be, as a conflict crystallizes, paralyzing reality, the indicator of the idea of the end of history, it is here agreed that the commemorations aiming the acknowledgment of Brazilian State crimes has also a preventive purpose, oriented by the representation of a shared future. This perspective corroborates that the learning of lessons from traumatic historical events can help preventing the recurrence of behavioral structure and patterns that allowed violence to be committed. Besides that, such adaptation acts oriented to the needs of the present - "in which rational alternatives for action are worked out" (JELIN, 2003, 
p. 91) - facilitate the process of reconciliation towards the restoration of social relationships based on fundamental values such as human dignity, respect, and physical and psychological dignity.

Even though symptomatic, the impression that the Brazilian society has never been able to get rid of the totalitarian trend, the current political struggle for acknowledgment of the State's injustices perpetrated in Brazil is trying to renounce the cold neutral observation, making room for the empathic surveillance and modes of mourning for the victims or their descendants. The act of making public the experiences forgotten (and/or repressed) by history, essential to assist to work through such social traumas, despite superficially covering a complex group of problems, as Saúl Sosnowski Claims (1994, p. 14-15), does not concern the conviction of being subjected to revive a forgotten past, let alone arbitrarily keeping symbols and themes worn out by changes or vague reiterations. It aims to avoid recidivism in denial and concerns the need of reworking an official painful memory that continues to be too porous to be forgotten, not forgetting what has been forgotten, of facing traumatic losses as a national mourning whose scars cannot be hidden, of dealing with the losses, the structural needs of the nation, and "the drive toward what and how we were, to what we no longer are, and to what and how we would like to be hereafter" (CLAIMS, 1994, p. 15).

At this point it makes sense to think that regardless of the feeling of injustice and indignation, and of the ascertainment that trials had not been conducted, the projects of official canonical enunciation (narratives) and recovery of the right to dissent public politics of reparation developed by the Brazilian reparation commissions - in resistance to deliberate oblivion - may have a symbolic and substantive therapeutic meaning, a civic action of awareness performing a didactic function of ritualized tribute that aspires so far as possible the recognition by other groups of its own grief and victimhood, overcoming a deficit of otherness that is essential for the very individual and collective self identity.

\section{Bibliography}

ABRÃO, Paulo; TORELLY, Marcelo D. O programa de reparações como eixo estruturante da justiça de transição no Brasil. In: REÁTEGUI, Félix (Ed.). Justiça de transição: manual para a América Latina. Brasília: Comissão de Anistia, Ministério da Justiça, 2011. p. 473-516.
ABRÃO, Paulo; TORELLY, Marcelo D. Mutações do conceito de anistia na justiça de transição brasileira: a terceira fase luta pela anistia. In. ARAUJO, Maria Paula; FICO, Carlos; GRIN, Monica (Org.). Violência na história: memória, trauma e reparação. Rio de Janeiro: Ponteio, 2012. p.177-197.

ADORNO, Theodor W. The meaning of working through the past. In: Critical models: interventions and catchwords. New York: Columbia University Press, 1998. p. 89-103.

ARTHUR, Paige. How "transitions" reshaped human rights: a conceptual history of transitional justice. Human Rights Quarterly, Baltimore, v. 31, n. 2, p. 321-367, May. 2009.

BALFOUR, Lawrie. Reparations after identity politics. Political Theory, New York, v. 33, n. 6, p. 786-811, Dec. 2005.

BARKAN, Elazar. KAN, Alexander. Taking wrongs seriously: apologies and reconciliation. Stanford: Stanford University Press, 2006.

BRAZIL. Ministry of Justice. Amnesty Commission. Activities report. Brasília: Comissão de Anistia, 2010.

DIMITRIJEVIC, Nenad. Duty to respond: mass crime, denial, and collective responsibility. New York: Central European University Press, 2011.

DIMOULIS, Dimitri. Justiça de transição e função anistiante no Brasil: hipostasiações indevidas e caminhos de responsabilização. In: DIMOULIS, Dimitri; MARTINS, Antonio; SWENSSON JUNIOR, Lauro Joppert (Org.). Justiça de transição no Brasil: direito, responsabilização e verdade. São Paulo: Saraiva, 2010. p. 91-127.

LACAPRA, Dominick. History and Memory After Auschwitz. Ithaca and London: Cornell University Press, 1998.

LACAPRA, Dominick. Writing history, writing trauma. Baltimore: The Johns Hopkins University Press, 2001.

LUDI, Regula. The vectors of postwar victim reparations: relief, redress and memory politics. Journal of Contemporary History, Madison, v. 41, n. 3, p. 421-450, Jun. 2006.

MAIER, Charles S. A surfeit of memory? reflections on history, melancholy and denial. History and Memory, Indiana, v. 5, n. 2, p. 136-152, Fall/Winter, 1993.

MALLINDER, Louise. Can Amnesties and international justice be reconciled? International Journal of Transitional Justice, Oxford, v.1, n. 2, p. 208-230, Jul. 2007.

MÉNDEZ, Juan; COVELLI, Tatiana Rincón. Parecer téc- 
nico sobre a natureza dos crimes de lesa-humanidade, a imprescritibilidade de alguns delitos e a proibição de anistias. In: SOARES, Inês Virgínia Prado; KISHI, Sandra Akemi Shimada (Org.). Memória e verdade: a justiça de transição no Estado Democrático brasileiro. Belo Horizonte: Fórum, 2009. p. 369-410.

MEZAROBBA, Glenda. Entre reparações, meias verdades e impunidade: o difícil rompimento com o legado da ditadura no Brasil. SUR: Revista Internacional de Direitos Humanos, São Paulo, v. 7, n. 13, p. 07-25, dez. 2010a.

MEZAROBBA, Glenda. O processo de acerto de contas e a lógica do arbítrio. In: TELES, Edson; SAFATLE, Vladimir (Org.). O que resta da ditadura: a exceção brasileira. São Paulo: Boitempo, 2010b. p. 109-119.

RÜSEN, Jörn. Mourning by history: ideas of a new element in historical thinking. Historiography East and West, Boston, v. 1, n. 1, p. 15-38, 2003.

SELIGMANN-SILVA, Márcio. A história como trauma. In: NESTROVSKI, Arthur; SELIGMANN-SILVA, Marcio. (Org.). Catástrofe e representação: ensaios. São Paulo: Escuta, 2000. p. 73-98.

SCHNEIDER, Nina. Breaking the 'silence' of the military regime: new politics of memory in Brasil. Bulletin of Latin American Research, New Jersey, v. 30, n. 2, p. 198-212, Apr. 2011.

SOARES, Inês Virgínia Prado. Memória democrática e desaparecidos políticos. In: SOARES, Inês Virgínia Prado; KISHI, Sandra Akemi Shimada (Org.). Memória e verdade: a justiça de transição no Estado Democrático brasileiro. Belo Horizonte: Fórum, 2009. p. 317-340.

SOSNOWSKI, Saúl. Contra os consumidores do esquecimento. In: SCHWARTZ, Jorge (Org.). O trânsito da memória. São Paulo: USP, 1994. p. 11-18.
SWENSSON JUNIOR, Lauro Joppert. Anistia penal: problemas de validade da Lei de Anistia brasileira (lei 6.683/79). Curitiba: Juruá, 2007.

TELES, Janaína de Almeida. Os familiares de mortos e desaparecidos políticos e a luta por "verdade e justiça" no Brasil. In: TELES, Edson; SAFATLE, Vladimir (Org.). O que resta da ditadura: a exceção brasileira. São Paulo: Boitempo, 2010. p. 253-298.

TELES, Edson Luís de Almeida. Brasil e África do Sul: os paradoxos da democracia: memória política em democracias com herança autoritária. 2007. 152 f. Tese (Doutorado) - Programa de Pós-Graduação em Filosofia, Faculdade de Filosofia, Letras e Ciências Humanas, Universidade de São Paulo, São Paulo, 2007.

TELES, Edson Luís de Almeida. Entre justiça e violência: Estado de Exceção nas democracias do Brasil e da África do Sul. In: TELES, Edson; SAFATLE, Vladimir (Org.). $O$ que resta da ditadura: a exceção brasileira. São Paulo: Boitempo, 2010. p. 299-318.

TORELLY, Marcelo D. Justiça de transição e estado constitucional de direito: perspectiva teórico-comparativa e análise do caso brasileiro. Belo Horizonte: Fórum, 2012.

TODOROV, Tzvetan. Memória do mal, tentação do bem.

São Paulo: Arx, 2002.

TODOROV, Tzvetan. Memory as a remedy for evil. London: Seagull Books, 2010.

TORPEY, John. Making whole what has been smashed: reflections on reparations. The Journal of Modern History, Chicago, v. 73, n. 2, p. 333-358, jun. 2001. 